\title{
ЛЕКСИКО-СЕМАНТИЧНІ ДЖЕРЕЛА ПРОБЛЕМИ КУЛЬТУРИ І ЦИВІЛІЗАЦІї
}

\section{O.I. Шрамко}

Проблема культури й цивілізації не нова для сучасної філософії. Вона має свою історію досліджень, у витоків якої стоїть велична постать I. Канта і яку можна простежити у роботах М.Бердяєва, Г. Зіммеля, О. Шпенглера, А. Тойнбі, А. Швейцера, П. Сорокіна, Ф. Броделя, Л. Уайта, Є. Михайловскої, Л.І. Новикової, Ю.В. Павленко, В.М. Шейко, та інших зарубіжних і вітчизняних мислителів.

Проте і на сьогоднішній день проблема культури й цивілізації залишається проблемою. Ї̈і актуальність зростає разом із зростанням цивілізаційної могутності людства і загостренням духовно-культурної кризи сучасного суспільства. Сьогодні питання про перспективи взаємовідношення культури і цивілізації та тенденції їхнього розвитку в найближчому та віддаленому майбутньому - це питання творення й самотворення нової духовності, на основі якої сучасна ідея мегакультури як загального знаменника розвитку глобальної цивілізації, як їі надихаючої сили з потенції здатна перетворитися на реальність. Тому актуальність проблеми культури й цивілізацї не підлягає сумніву і зумовлює виявлення тих аспектів проблеми, які здатні висвітлити її сутнісні характеристики.

Одним з таких аспектів є дослідження лексико-семантичних джерел проблеми культури й цивілізації, що й склало мету даної роботи. В основі дослідження - лексико-семантична еволюція термінів «культура» й «цивілізація» від появи відповідних лексем до становлення їх як ключових і найвпливовіших категорій сучасного наукового пізнання.

Щодо етимології, то і «культура», і «цивілізація» мають єдине походження - латинське: cultura від colere - «оброблювати»; civilization

Актуальні проблеми духовності

(Відп. ред.: Я.В. Шрамко)

Кривий Ріг (2006), 436-444 
від civilis - громадянський. Спільність можна простежити і в тому, що ті багатогранні значення, яких обидва слова набули у подальшому, кардинально відрізняються і від етимології, і від практики їхнього давнього вживання.

Так, латинське cultura спочатку означало «оброблене», «штучне» на противагу «природному», «первозданному», «дикому» і застосовувалося насамперед для розрізнення дикорослих рослин і тих, що вирощувалися людьми. Тільки з часом слово «культура» стало вбирати все ширше коло предметів, явищ, дій, загальними властивостями яких був їх неприродний або «протиприродний» характер, їх людинотворче, а не божественне чи природне походження. Відповідно і сама людина тією мірою, якою вона розглядалася як творець себе самої, як плід перетворення богоданного або природного матеріалу, попадала у сферу вживання слова «культура», яке поступово починало розумітися як «освіта» або «виховання».

Латинське civilis також мало небагато спільного з тим смислом, виразником якого було покликане стати створене Просвітництвом слово «цивілізація». Civilis вживалося, коли мова йшла про якості громадянина - мешканця міста. Під цим словом мали на увазі насамперед пристосованість до міського життя - люб'язність, привітність, чемність, увічливість тощо.

Лексико-семантична площина аналізу термінів «культура» $\mathrm{i}$ «цивілізація» відразу ж наштовхує нас на суттєву різницю в лексичному та семантичному розвитку останніх. Як відомо, семантичне сходження латинської лексеми «культура» було набагато довшим, а головне, важчим, ніж французької «цивілізації». Тобто, від слова cultura до сучасного поняття культури, яке почало складатися лише у Нові часи, пройшло не одне століття. Набагато більше пощастило поняттю «цивілізація», яке стверджувалося одночасно з виникненням однойменної лексеми. Але найцікавішим $є$ те, що «морфологічно абсолютно різні слова (культура і цивілізація), що виникли у зовсім несхожі часи, починають семантично стикатися в певну епоху (середина віку Просвітництва)» [2, с. 110]. До того ж, ця епоха стала не лише часом семантичної «зустрічі» двох слів, для кожного з них вона виявилася ключовим моментом розвитку - саме в цей час разом зі словом народжується поняття цивілізації, значення самостійного узагальненого поняття набуває також і слово «культура».

Появу поняття «культура» пов'язують з працями німецького юриста та історика Самуеля Пуфендорфа, який перший наблизився до розуміння самостійного значення слова «культура», адже до XVII сто- 
ліття в європейських мовах це слово позначало переважно функцію іншого слова, у сполученні з яким найчастіше і вживалося - від найдавніших cultura agri («обробка землі») та cultura animi («виховання душі») до більш пізніх cultura scientiae («засвоєння знань, набуття досвідченості»), cultura juris («вироблення правил поведінки»), cultura litterarum («удосконалювання писемності») тощо.

Від Пуфендорфа бере початок осмислення культури як певного ступеня розвитку людини і суспільства - як сукупність досягнень людини в результаті оволодіння природою, а також як внутрішне удосконалення людини завдяки вихованню та освіті. Усе частіше поняття культури стало вживатися не лише як протистояння людини та її діяльності дикій стихії природи, але й в значенні освіченості, вихованості людини. Цей смисл чогось позаприродного, того, що розвинуте і культивується людиною, зберігся у понятті «культура» і до теперішнього часу. I все ж полісемія поняття «культура», яка виявилася вже наприкінці XVII століття, була дещо прихована закріпленням до середини наступного століття за словом «культура» узагальненого значення певного ступеня суспільного розвитку. Тож не дивно, що з появою слова «цивілізація», яке одразу спробувало зайняти ту ж саму семантичну нішу, ці два слова - «культура» і «цивілізація»-стають і конкурентами, і синонімами.

Проте історія паралельного існування цих слів протягом XVIIIXIX століть відзначається очевидною нерівномірністю їхньої суспільно-громадської й наукової популярності. Так, слово «цивілізація» набуває свого інтенсивного функціонування лише наприкінці XVIII століття. Виникає ж воно дещо раніше - першу його появу у французькій мові пов'язують з виступами молодого Тюрго в Сорбонні (1752р.), письмову ж фіксацію найвідоміші дослідники історії слова «цивілізація» реєструють по-різному - Л. Февр, опрацювавши величезну кількість відповідної літератури і спираючись на Буланже та барона де Гольбаха, датує це слово 1766 роком [4, с. 242-243], Е. Бенвеніст, посилаючись на роботи Фердинанда Брюно, Йоахіма Мораса та власні дослідження текстів, вказує на більш ранні випадки вживання цього слова і відмічає рік 1757, коли світ побачив твір маркіза де Мірабо «Друг людей, або Трактат про народонаселення» [1, с. 387-389].

Швидко розповсюдившись в багатьох європейських мовах, до середини XIX століття лексема «цивілізація» втрачає свою популярність. Як відмічає Р.А.Будагов, вона «стала вживатися набагато рідше, ніж культура, а в деяких мовах перетворилася навіть на архаїчну одиницю (наприклад, в німецькій, почасти в російській)» [2, с. 122-123]. 3 кін- 
ця ж XIX століття культура й зовсім відтискує цивілізацію на другий план [2, с. 125].

Цей лише невеликий екскурс в історію співіснування лексем «культура» $\mathrm{i}$ «цивілізація» $\epsilon$ першим і необхідним щаблем до прояснення генези проблеми культури і цивілізації, адже ставить питання більш вагомого гатунку - питання, що стосуються історії співіснування означених понять.

Питання перше: навіщо знадобився неологізм «цивілізація» і саме в той час, коли за словом «культура» вже майже закріпилося значення певного ступеня суспільного розвитку?

Питання друге: в чому полягає специфіка семантичної «зустрічі» термінів «культура» й «цивілізація» і чим пояснюється нерівномірність інтенсивності використання означених понять в країнах Західної Європи, якщо з самого початку спільного життя в гуманітарному просторі були всі підстави для їх синонімічного вживання?

Спробуємо знайти відповіді на ці питання, вибудовуючи таким чином історію співіснування понять «культура» і «цивілізація».

Перше питання повертає нас до багато в чому переломної епохи в розвитку суспільно-громадської й філософської думки Західної Європи - епохи Просвітництва і надає можливість більш глибокого погляду на духовну атмосферу народження лексеми «цивілізація». Важливість такої розвідки влучно підкреслював Е. Бенвеніст, коли писав, що «вся історія сучасної думки і головні надбання духовної культури в західному світі пов'язані з тим, як люди створюють і як вони поводяться 3 декількома десятками основних слів, сукупність яких складає загальний набуток мов Західної Європи» [1, с. 386]. Особливо це актуально по відношенню до терміну «цивілізація», адже «цивілізація є одним 3 тих слів, які несуть з собою нове бачення світу» $[1$, с. 386].

Одна з найперших і найвагоміших спроб відтворити історію слова «цивілізація» «і тим самим охопити поглядом - 3 особливої точки зору - історію, інтерес і значення якої не обмежуються кордонами однієї держави» [4, с. 239] належить французькому досліднику Люсьєну Февру, який вважав таку роботу реконструкцією етапів найглибшої революції, яку здійснила і через яку пройшла французька думка з другої половини XVIII століття і до нашого часу [4, с. 239].

Февр блискуче реконструює перший етап цієї глибокої революції французької думки і показує, що час виникнення іменника «цивілізація» не $\epsilon$ випадковим і що саме в цей час виникає потреба в терміні, значення якого було б спроможним замінити психологічно навантажені значення слів civilite, politesse, police, за допомогою яких на протязі 
всього XVII століття французькі автори класифікували вищий ступінь розвитку народів після ступенів «дикунства й «варварства» [4, с. 249255]. Цим терміном і став неологізм «цивілізація», який виражав нове поняття, здатне в абстрактній категорії виразити уявлення про певний ступінь суспільного розвитку людства.

Можливість появи такої абстракції теж не випадкова. Її детермінували цілком конкретні, кардинальні зрушення в соціально-історичному розвитку Франції. Це час, коли під впливом філософських ідей Бекона, Декарта, Ньютона, Локка, наукових та географічних відкриттів починають формуватися загальні теорії, розвивається «велика ідея раціональної й експериментальної науки, єдиної у своїх методах і підходах - чи йде справа про підкорення природи ... чи про те, щоб слідом за Монтеск'є зводити людські суспільства з їх нескінченним різноманіттям в абстрактні категорії» [4, с.255]. Цілком логічно, що на цьому грунті «виникає не релятивістське уявлення про етнічні або історичні цивілізації, з яких кожна має свої особливості й, безперечно, індивідуальна, а абсолютне уявлення про людську цивілізацію, цілісну й одноманітну» $[4$, с. 258]. Отже, потреба часу - потреба в абсолютноабстрактних, ідеальних, синтетичних поняттях - i народила відповідне поняття «цивілізації».

Про абсолютність, абстрактність і ідеальність поняття цивілізації говорить той факт, що більшість авторів французького Просвітництва розуміли цивілізацію як сходження до розуму, а ㄲï джерелом вважали розвиток знань і просвітництво. «Просвітити націю, - писав Д. Дідро, - значить цивілізувати їі; відібрати в неї знання - значить повернути її у первісний стан варварства» [4, с. 260]. Такої ж думки притримувався і Гольбах, коли відмічав, що «послідовна низка кроків пізнання веде людину від дикого стану до такого, в якому ми бачимо її в цивілізованому суспільстві, де вона займається найвищими науками і оволодіває найскладнішими знаннями» [4, с. 261].

Про характерне для епохи Просвітництва смислове навантаження нового терміну говорять і перші приклади використання слова «цивілізація», наведені Е.Бенвеністом. Блискучий лінгвіст, Е.Бенвеніст проводить ретельне дослідження найперших випадків вживання слова «цивілізація» в роботах французьких, англійських та шотландських мислителів - Мірабо, Буланже, Босуела, Ричарда Прайса, Адама Сміта, Джона Міллара, Адама Фергюсона [1]. Вважаючи мову природним середовищем розвитку понять, Е. Бенвеніст намагається генетично визначити поняття цивілізації через історію його становлення в мові. Цей метод, застосований дослідником для розв'язання суто лінгвістичних 
завдань, виявляє свою продуктивність і у вирішенні питання щодо еволюції філософського поняття цивілізації.

Серед наведених Е.Бенвеністом прикладів показовими $\epsilon$ вже вислови Мірабо («Друг людей, або Трактат про народонаселення», «Теорія податку», незакінчений рукопис з багатообіцяючою назвою «Друг жінок, або Трактат про цивілізацію»): «Служителі релігії правомірно займають перші місця в добре упорядкованому суспільстві. Релігія, безперечно, найкраща й найкорисніша вузда людства; це головна пружина цивілізації; вона наставляє нас і безперестанно нагадує нам про братство, пом'якшує наше серце тощо»; «викорінення цих забобонось що спричиняють знання, що надає цивілізація»; «чесні люди бережуть свою чесність і своє серце для своєї поведінки, а свою цивілізацію і свій розум - для суспільства»; «цивілізація та звичай зобов'язують їх зменшувати своє значення в суспільстві»; «Я дивуюся при цьому, наскільки хибні наші погляди стосовно того, що ми приймаємо за цивілізацію, через хибні у всіх пунктах пошуки. Якщо б я спитав у більшості, у чому, на вашу думку, полягає цивілізація, то мені відповіли б: цивілізація $є$ пом'якшення звичаїв, чемність, увічливість і знання, що розповсюджуються для того, щоб дотримувалися правила пристойності і щоб ці правила відігравали роль законів співжиття; усе це являє мені лише маску доброчесності, а не її обличчя, і цивілізація нічого не здійснює для суспільства, якщо вона не дає йому основи й форми доброчесності» [1, с. 388-389].

Наведені приклади дозволяють зробити декілька висновків. Поперше, на початку свого існування новий термін зберігає ще смисл, закладений у дієслові civiliser («цивілізувати, що означало пом'якшувати звичаї, освічувати») і дієприкметнику civilise («цивілізований, тобто добре вихований, освічений»), які вже давно були в широкому вжитку і більше відображали ствердження аристократичних норм шляхетності, освіченості й вихованості, ніж потреби просвітницької епохи. Про це говорить і фіксація цих значень наведених слів у «Загальному словнику» А.Фуретьєра, виданому в Голландії ще у 1690 році: «Селяни не так цивілізовані, як буржуа, а буржуа - не такою мірою, як придворні» ([4, с. 252], [3, с. 13]).

I все ж, ясно простежується новий смисл i «освіченості», i «вихованості» - ці означення характеризують вже цивілізацію як певний ступінь розвитку суспільства, більш впорядкованого, більш раціонального і більш пристосованого для суспільного співіснування, в напрямку якого, як вважали просвітники, повинна прямувати і окрема людина, і все людство: «Не лише індивід,- писав у 1767 році Адам Фергю- 
сон, - просувається вперед від дитинства до зрілого віку, а й сам рід людський від варварства до цивілізації [1, с. 394].

Тобто, в понятті цивілізації вбачали, насамперед, ідеал епохи Просвітництва - розумне, освічене, засноване на раціональних засадах суспільство. Наряду зі знаннями, освіченістю цей ідеал включав моральні принципи, свободу, справедливість і правосуддя, подолання рабства й злиднів, припинення війн. Так, Фергюсон розуміє цивілізацію як певний порядок, «певну безпеку особистості й власності, що ми і називаємо цивілізацією», як вплив «закону і політичного устрою на форми суспільства» $[1$, с. 396]. Рейналь - як звільнення від рабства: «Звільнення від рабства, або, що одне й те саме, назване іншим іменем, цивілізація якого-небудь царства, - справа довга і важка»; як верховенство закону і справедливості, втілених у правосудді: «Ми спитаємо: чи можлива цивілізація без правосуддя і справедливості?» [4, с.261]. Кондорсе - як світоч миру і свободи: «Освіченість цивілізованих народів назавжди убезпечить Європу від вторгнень; і чим ширше розповсюдиться по Землі цивілізація, тим скоріше будуть зникати війни та завоювання, рівно як рабство і злидні» [4, с. 260].

Розуміння цивілізації як ідеалу Просвітництва цілком відповідало світоглядним уявленням епохи - безмежній вірі в удосконалювання людини й людства, вираженій в понятті прогресу. Ідеал цей стверджувався по мірі наближення до революційних подій кінця XVIII століття. «3 наближенням революції слово «цивілізація» святкує перемогу» [4, c. 245], адже «революційний рух неминуче був рухом оптимістичним, повністю зверненим до майбутнього. За цим оптимізмом стояла філософія, що підтримувала й виправдовувала його: філософія прогресу, безмежного удосконалювання людських істот та їх творінь» [4, с. 266]. Отже, поява терміну «цивілізація» і майже одночасне ствердження поняття цивілізації не просто відповідало вимогам епохи, а було логічною відповіддю на виклик часу, відповіддю, яка сконцентрувала світоглядні уявлення європейців і про сучасний стан свого суспільного буття, i про своє майбутнє, що пов'язувалося з прогресом як загальною долею всього людства. Дещо пізніше ці уявлення спробував виразити Франсуа Гізо, який у 1828 році писав: «Ідея прогресу, розвитку уявляється мені основною ідеєю, що міститься у слові «цивілізація» [4, с. 273].

Тепер спробуємо розібратися, чому французьке Просвітництво не скористалося відомим тогочасній Європі словом «культура», і не просто відомим, а таким, що набуло вже статусу самостійного поняття, за яким закріпилося в числі інших і значення певного ступеня суспільного розвитку. Відразу ж звертає на себе увагу майже повне ігнорування 
терміну «культура» у роботах французьких просвітників. Для середини і другої половини XVIII століття в Європі це більше, ніж дивно. Тому цей факт потребує пояснень. Серед останніх принаймні два переконливих.

По-перше, доволі вузьке й однозначне розуміння слова «культура» у французькій мові. «Академічний словник» 1762 року вказує на «піклування про мистецтва і розумову діяльність», 1835 року - на діяльність, спрямовану «на удосконалювання наук та мистецтв, на розвиток розумової діяльності» [4, с. 275].

По-друге, і це уявляється головним, спроба поєднати в понятті цивілізації смисли, вже на той час обгрунтовано розірвані у сусідній Нiмеччині - уявлення про могутнє суспільство, яке досягло певного ступеня суспільної упорядкованості й добробуту і при цьому не суперечить вільному розвитку та збагаченню здібностей, думок і почуттів морально досконалої особистості, а також розвитку наук і мистецтв.

Спроба такого синтезу простежується вже на підступах до створення поняття «цивілізація» - в уявленнях про народи polices, у яких «сила підпорядкована законам, які попереджують і приборкують її буйство», і «заслужена почесть віддається духовним якостям» [4, с. 252]. Тобто, на етапі пошуку слова, «яке означає торжество і розквіт розуму не лише у сфері законності, політики й управління, а і в області моральній, релігійній та інтелектуальній» [4, с. 253]. Пізніше зазначена інтегрованість смислів у французькому понятті «цивілізація» чітко підкреслена Ф.Гізо: «Навіть такі явища, котрі, власне кажучи, не можна назвати соціальними, - індивідуальні явища, які, здавалося б, більше відносяться до людської душі, ніж до суспільного життя, такі релігійні вірування і філософські ідеї, науки, література і мистецтва», - вони також можуть і повинні розглядатися «3 точки зору цивілізації» [4, с. 272].

Саме Гізо чи не найпершим з європейських мислителів звернув увагу на важливість єдності та взаємодії двох головних елементів успішного розвитку цивілізації- соціального та інтелектуального, за якими він вбачав «з одного боку, ... розвиток умов зовнішніх по відношенню до людини і загальних; з іншого - розвиток внутрішньої і особистої природи людини; ... удосконалювання суспільства і таке ж-аспектів людських» 4 , с. 273]. I саме Гізо спробував представити Францію як країну, яка спромоглася «сміливо здійснити гармонічний розвиток думки і дійсності, сторони інтелектуальної і сторони реальної», адже у Франції «природа ніколи не обділяла людей ні особистою величчю, ні достоїнствами, а особиста велич і достоїнства завжди мали суспільне 
значення і могли бути корисними суспільству» [4, с. 274]. Навпаки, в англійській цивілізації Гізо вбачав орієнтованість виключно на покращення соціальне, а в німецькій - на розвиток сторони інтелектуальної, торжество людського духу над матеріальними умовами існування.

Отже, цілком ймовірно, що захопившись власною «цивілізованістю» і відповідно, розвитком поняття цивілізації, французи безболісно пройшли повз термін «культура», включивши багатогранність його смислів до поняття «цивілізація». Це припущення дозволяє зрозуміти, чому французька гуманітарна традиція протягом XIX-XX століть віддає перевагу терміну «цивілізація» і майже не переймається проблемою культури і цивілізації.

Це також дозволяє прояснити і питання стосовно особливостей семантичної «зустрічі» термінів «культура» і «цивілізація» в країнах Західної Європи, які найяскравіше продемонстрували дві протилежні проекції такої «зустрічі» - інтеграційно-нейтральну і принципово антагоністичну. Цими країнами стали Франція і Німеччина. Як відомо, до французького поняття «цивілізація», яке було запозичене німцями, останні відносилися з помітною неприязню і у німецькій філософській літературі XVIII-XX століть перевага віддавалася слову «культура». Причини цього явища неоднозначні і потребують окремого дослідження, яке дозволить пояснити чому саме в Німеччині народилася ідея протиставлення культури і цивілізації.

\section{1 Бібліографія}

[1] Бенвенист Э. Цивилизация. К истории слова // Бенвенист Э. Общая лингвистика. - М.: Прогресс, 1974.-С. 386-396.

[2] Будагов Р.А. Природа и культура в истории общества (природа, натура, культура, цивилизация) // Будагов Р.А. История слов в истории общества. - М.: Просвещение, 1971. - С. 108-133.

[3] Eрасов Б.С. Цивилизации: Универсалии и самобытность. - М.: Наука, 2002.

[4] Февр Л. Цивилизация: эволюция слова и группы идей // Февр Л. Бои за историю. - М.: Наука, 1991. - С. 239-281. 